\title{
Long Non-coding RNAs as Regulators of the Mitogen-activated Protein Kinase (MAPK) Pathway in Cancer
}

\author{
Dlouhé nekódující molekuly RNA jako regulátory mitogenem \\ aktivované proteinkinázové dráhy (MAPK) v nádorech
}

\author{
Tasharrofi B., Ghafouri-Fard S. \\ Department of Medical Genetics, Shahid Beheshti University of Medical Sciences, Tehran, Iran
}

\begin{abstract}
Summary
Background: The mitogen-activated protein kinase (MAPK) pathway contributes to regulation of many cellular functions, such as cell proliferation and differentiation, mobility and apoptosis. Extracellular signal-regulated kinase 1/2 (ERK1/2), c-Jun N-terminal kinase (JNK)/p38 and ERK5 construct the three main modules in this pathway. The Raf-ERK $1 / 2$ and JNK cascades contribute in cell proliferation, migration, and survival and are principal regulators of malignant phenotype. This pathway is itself regulated by several outside signals as well as lateral signals from other pathways, which construct a complex network. Long non-coding RNAs (IncRNAs) as principal modulators of gene expression at transcriptional and post-transcriptional levels also regulate this pathway. In addition, IncRNA signature can be used as biomarker and target of novel treatment strategies in cancer patients. Aim: To explore the role of IncRNAs in regulation of MAPK pathway. Conclusion: Considering the role of this pathway in the pathogenesis of several cancers, alterations in IncRNA expression lead to changes in MAPK pathway resulting in inhibition of apoptosis and induction of cell proliferation and migration. Moreover, some IncRNAs participate in cross-talk between MAPK and other cancer-related pathways, such as $\mathrm{PI} 3 \mathrm{~K} /$ Akt pathway through regulation of certain shared proteins between these pathways. Based on the availability of certain anticancer drugs that modulate this pathway, identification of IncRNAs that affect this pathway would help in establishment of effective therapies.
\end{abstract}

Key words

RNA - long noncoding - mitogen-activated protein kinases - signal transduction

\section{Souhrn}

Úvod: Mitogenem aktivovaná proteinkinázová dráha (MAPK) přispívá k regulaci mnoha buněčných funkcí, jako je proliferace a diferenciace buněk, mobilita a apoptóza. Extracelulární signálně regulovaná kináza 1/2 (ERK1/2), c-Jun N-terminální kináza (JNK)/p38 a ERK5 jsou tři hlavní moduly $v$ této dráze. Kaskády Raf-ERK1/2 a JNK přispívají k proliferaci buněk, migraci a přežití a jsou hlavními regulátory maligního fenotypu. Tato dráha je sama regulována několika vnějšími signály, stejně jako bočními signály z jiných signálních drah, které vytvářejí komplexní sít. Dlouhé nekódující RNA (IncRNA) jako hlavní modulátory genové exprese na transkripční a posttranskripční úrovni a také regulují tuto dráhu. Kromě toho můžou IncRNA sloužit jako biomarker a cíl nových léčebných strategií u pacientů s nádory. Cíl: Prozkoumat roli IncRNA v regulaci dráhy MAPK. Závěr: Vzhledem $\mathrm{k}$ úloze této dráhy $\mathrm{v}$ patogenezi několika typů nádorů dochází ke změnám exprese IncRNA, které vedou ke změnám $v$ dráze MAPK, což vede $k$ inhibici apoptózy a indukci buněčné proliferace a migrace. Některé IncRNA se navíc podílejí na spojení mezi MAPK a jinými drahami souvisejícími s nádory, jako je dráha PI3K/Akt prostřednictvím regulace určitých sdílených proteinů mezi těmito drahami. Na základě dostupnosti některých protinádorových léčiv, modulujících tuto dráhu, by identifikace IncRNA, ovlivňující tuto dráhu pomohla při vytváření účinných terapií.

\section{Klíčová slova}

RNA - dlouhé nekódování - mitogenem aktivované proteinové kinázy - signální transdukce
The authors declare they have no potential conflicts of interest concerning drugs, products, or services used in the study.

Autoři deklarují, že $v$ souvislosti s predmětem studie nemají žádné komerční zájmy.

The Editorial Board declares that the manuscript met the ICMJE recommendation for biomedical papers.

Redakční rada potvrzuje, že rukopis práce splnil ICMJE kritéria pro publikace zasílané do biomedicínských časopisů.

\section{$\equiv^{\circ}$}

Soudeh Ghafouri-Fard, MD, PhD Department of Medical Genetics Shahid Beheshti University of Medical Sciences Bldg No.2 SBUMS Arabi Ave, Daneshjoo Blvd, Velenjak Tehran, Iran e-mail: s.ghafourifard@sbmu.ac.ir

Submitted/Obdrženo: 5. 12. 2017 Accepted/Prijato: 5. 2. 2018

doi: 10.14735/amko201895 


\section{Introduction}

The mitogen-activated protein kinase (MAPK) pathway contributes to a wide range of cellular functions, such as cell proliferation and differentiation, mobility and apoptosis. Several lines of evidence suggest that this pathway does not work as a linear signaling pathway that directly conveys certain signals to a definite cellular response. Instead, several outside signals as well as lateral signals from other pathways contribute to construction of a complex network through which MAPK pathway operates [1]. Abnormal regulation of this pathway participates in the pathogenesis of several malignancies [2]. Extracellular signal-regulated kinase $1 / 2$ (ERK1/2), c-Jun N-terminal kinase (JNK)/ p38 and ERK5 construct the three main modules in this pathway [2]. The RafERK $1 / 2$ and JNK cascades contribute to cell proliferation, migration, and survival and are principal regulators of malignant phenotype [3].

Among putative regulators of this pathway are long non-coding RNAs (IncRNAs). LncRNAs make a high pro- portion of human transcripts, which are not translated to proteins $[4,5]$. With sizes more than 200 base pairs, they regulate expression of protein coding genes a well as microRNAs (miRNAs) [6]. Subsequently, they affect telomere biology, chromatin dynamics, genome structure organization [7], DNA repair [8] and tissue homeostasis [9]. They also participate in tumorigenesis process via different mechanisms, such as transcription repression [10], induction of epithelial-mesenchymal transition (EMT) [11], inhibition of tumor suppressors expression [12,13], over-expression of certain oncogenes [14,15], regulation of tumor-associated signaling pathways [16] as well as modulation of tumor microenvironment [17]. Recently, a handful of IncRNAs have been shown to regulate the MAPK pathway through modulation of the expression of different proteins within this pathway. We discuss specific roles of these IncRNAs in the following sections. Special site of their action in the MAPK pathway has been demonstrated in Fig. 1. In addition, their characteristics, such as their genomic location and their expression pattern in cancers have been summarized in Tab. 1 .

\section{Antisense RNA in the INK4 locus (ANRIL)}

Aberrant expression of ANRIL has been detected in a variety of cancers including glioma in which its expression has been associated with tumor grade and patients survival. In vitro studies have shown that ANRIL silencing results in suppression of cell proliferation as well as induction of cell cycle arrest and apoptosis in glioma cells by modulation of expression of ERK, JNK and p38 from MAPK signaling pathway [18].

\section{BMP/OP-Responsive Gene (BORG)}

The expression levels of this IncRNA have been associated with invasive and metastatic potential of breast tumors. Its role in breast cancer pathogenesis is exerted through binding with Tripartite Motif Containing 28 (TRIM28) protein and subsequent enhancement of its localization and transcriptional repressive activity. BORG-expressing breast cancer cells attain metastatic

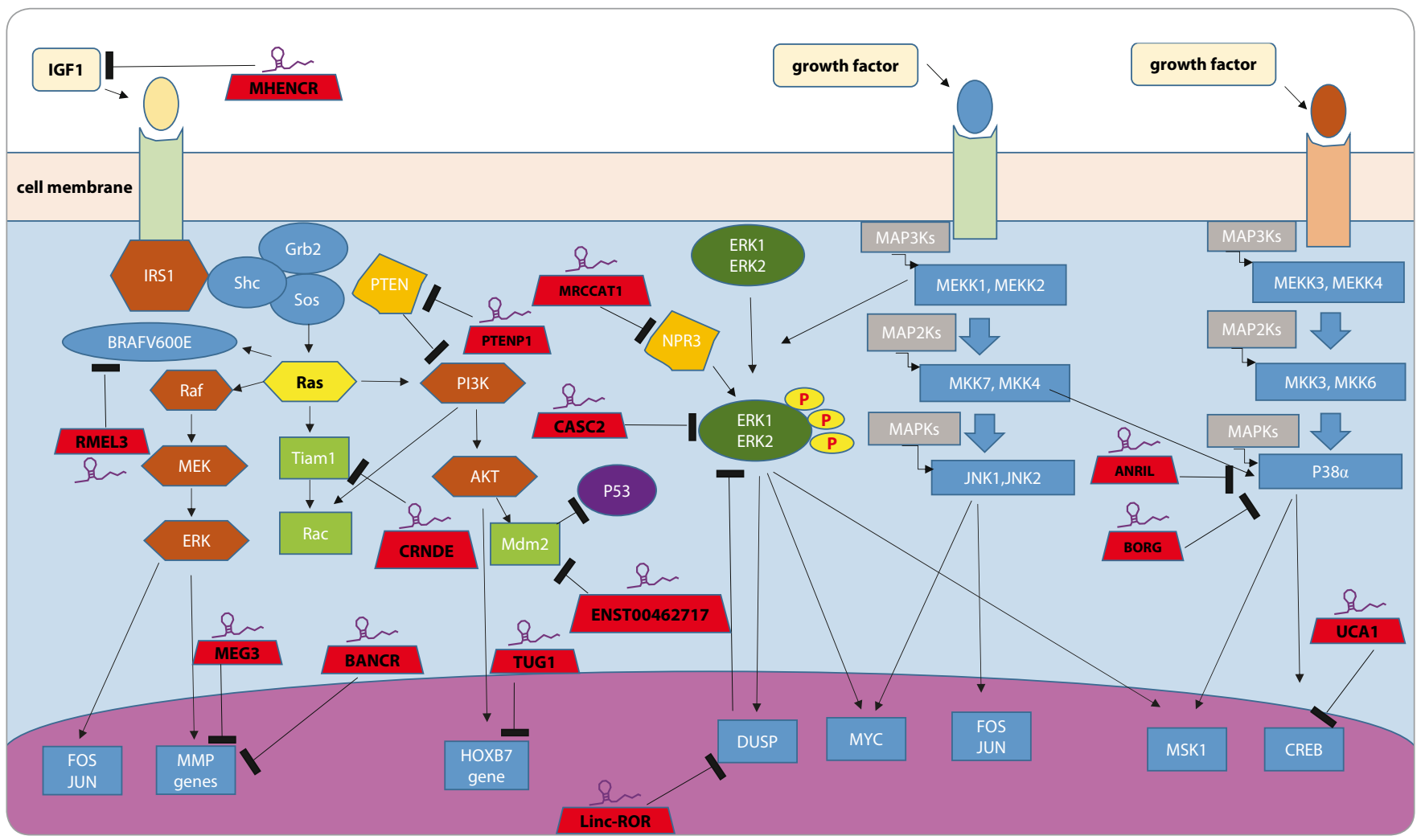

Fig. 1. Schema of mitogen-activated protein kinase (MAPK) pathway with several proteins involved in it. Long non-coding RNAs (demonstrated in red terapeziuses) regulate this pathway at several points. 
Tab. 1. Detailed characteristics of long non-coding RNAs that regulate MAPK pathway.

\begin{tabular}{|c|c|c|c|c|}
\hline LncRNAs & Location & $\begin{array}{l}\text { Expression } \\
\text { pattern }\end{array}$ & Cancer & Role \\
\hline UCA1 & $19 p 13.12$ & up & bladder & regulation of expression and phosphorylation of AKT and CREB \\
\hline Linc-ROR & $18 q 21.31$ & up & breast & $\begin{array}{l}\text { decreasing the stability of negative regulator of ERK } \\
\text { (phosphatase DUSP7) }\end{array}$ \\
\hline PTENP1 & 9 p21 & down & breast & $\begin{array}{l}\text { regulation of the expression of PTEN, inhibition of cell } \\
\text { proliferation and growth, cell cycle and migration }\end{array}$ \\
\hline CYTOR & $2 \mathrm{p} 11.2$ & up & breast & cell proliferation, cell migration, cytoskeletal organization \\
\hline BORG & - & up & breast & regulation of p38 MAPK activity \\
\hline CRNDE & $16 q 12.2$ & up & colorectal & regulation of Tiam1, GRB2 and RIN1 expression \\
\hline BANCR & $9 q 21$ & up & endometria & $\begin{array}{l}\text { regulation of cancer cell proliferation andinvasion by regulating } \\
\text { MMP2 and MMP1 }\end{array}$ \\
\hline MALAT1 & $11 q 13.1$ & up & $\begin{array}{l}\text { gallbladder carcino- } \\
\text { ma, neuroblastoma }\end{array}$ & $\begin{array}{l}\text { regulation of proliferation and metastasis, growth rate and } \\
\text { invasion }\end{array}$ \\
\hline CASC2 & $10 q 26.11$ & down & gastric & regulation of proliferation via ERK $1 / 2$ and JNK inactivation \\
\hline ANRIL & $9 p 21.3$ & up & glioma & regulation of proliferation via p38, ERK1/2 and JNK activation \\
\hline MALAT1 & $11 q 13.1$ & down & glioblastoma & regulation of phosphorylated ERK $1 / 2$ levels \\
\hline HULC & $6 p 24.3$ & up & glioma & important role in angiogenesis and tumor aggravation \\
\hline MALAT1 & $11 q 13.1$ & up & several cancers & $\begin{array}{l}\text { regulation of cell proliferation and invasion by changing MMP2 } \\
\text { expression }\end{array}$ \\
\hline CASC2 & $10 q 26.11$ & down & $\begin{array}{l}\text { hepatocellular } \\
\text { carcinoma }\end{array}$ & $\begin{array}{l}\text { regulation of cell proliferation, migration, invasion and apoptosis } \\
\text { via } 338 \text {, ERK } 1 / 2 \text { and JNK activation }\end{array}$ \\
\hline Igf2as & $11 \mathrm{p} 15.5$ & up & $\begin{array}{l}\text { hepatocellular } \\
\text { carcinoma }\end{array}$ & regulation of cell proliferation, apoptosis and invasion \\
\hline BANCR & $9 q 21$ & up & melanoma & $\begin{array}{l}\text { regulation of cell proliferation and migration via ERK } 1 / 2 \text { and JNK } \\
\text { activation }\end{array}$ \\
\hline RMEL3 & & up & melanoma & increase cell survival and proliferation \\
\hline LnCRNA-LET & & down & $\begin{array}{l}\text { nasopharyngeal } \\
\text { carcinoma }\end{array}$ & $\begin{array}{l}\text { induction of cell cycle arrest in G0/G1 phase by phosphorylation } \\
\text { of ERK } 1 / 2\end{array}$ \\
\hline TUG1 & $22 q 12.2$ & down & $\begin{array}{l}\text { non-small cell lung } \\
\text { cancer }\end{array}$ & control of cell proliferation through control of HOXB7 \\
\hline MEG3 & $14 q 32.2$ & down & breast & $\begin{array}{l}\text { regulation of cell proliferation, invasion, and angiogenesis by } \\
\text { downregulating PCNA, MMP-9 and VEGFA }\end{array}$ \\
\hline MHENCR & $20 q 13.33$ & up & melanoma & $\begin{array}{l}\text { regulation of cell proliferation, cell cycle arrest, apoptosis and } \\
\text { migration by bounding to miR- } 425 \text { and miR- } 489 \text {, upregulation of } \\
\text { their target genes IGF1 and SPIN1 expression }\end{array}$ \\
\hline MRCCAT1 & $5 q 15$ & up & $\begin{array}{l}\text { clear cell renal cell } \\
\text { carcinoma }\end{array}$ & $\begin{array}{l}\text { regulation of metastasis, proliferation and migration via } \\
\text { inhibiting NPR3 by recruiting PRC2 to NPR3 promoter }\end{array}$ \\
\hline $\begin{array}{l}\text { ENSTO04 } \\
62717\end{array}$ & & down & glioma & $\begin{array}{l}\text { regulation of cell proliferation, survival and migration by } \\
\text { inhibiting MDM2 }\end{array}$ \\
\hline AWPPH & & up & $\begin{array}{l}\text { hepatocellular } \\
\text { carcinoma }\end{array}$ & regulation of YBX1-mediated activation of SNAIL1 translation \\
\hline URHC & $2 q 31$ & up & $\begin{array}{l}\text { hepatocellular } \\
\text { carcinoma }\end{array}$ & regulation of proliferation and apoptosis via ZAK \\
\hline IncARSR & & up & $\begin{array}{l}\text { hepatocellular } \\
\text { carcinoma }\end{array}$ & regulation of drug response via decreasing PTEN expression \\
\hline CCHE1 & $10 q 21.1$ & up & $\begin{array}{l}\text { hepatocellular } \\
\text { carcinoma }\end{array}$ & regulation of cell growth and apoptosis \\
\hline CCAT1 & $8 q 24.21$ & up & medulloblastoma & regulation of cell proliferation and metastasis \\
\hline
\end{tabular}


characteristics through inhibition of p38 MAPK activity and enhancement of ERK1/2 function. This BORG-mediated alteration in MAPK function was TRIM28 dependent as demonstrated by high p38 MAPK : ERK1/2 activity ratios in TRIM28 silenced cells [19].

\section{BRAF-activated non-coding RNA (BANCR)}

Elevated expression of BANCR has been detected in human malignant melanoma cell lines and tissues. BANCR silencing has suppressed proliferation of tumor cells and inhibited MAPK pathway through down-regulation of ERK1/2 and JNK [3]. In addition, $B A N C R$ silencing in endometrial cancer cells inhibited their proliferation and arrested the cell cycle at G0/G1.BANCR anti-apoptotic role is possibly exerted through up-regulation of Cyclin D1 and $\mathrm{BCl}-2$. Besides, BANCR activates ERK/MAPK pathway and then induces expression of matrix metalloproteinases 1 and 2 (MMP1 and MMP2) in endometrial cancer cells leading to enhancement in proliferation, migration, and invasion of these cells [20]. In colorectal cancer (CRC) and lung cancer, BANCR activates mitogen-activated protein kinase (MEK)/ERK and JNK/MAPK pathways, resp. $[21,22]$

\section{Cancer susceptibility candidate 2 (CASC2)}

Its role as a tumor suppressor gene was first demonstrated in endometrial cancer in which its down-regulation has been detected $[23,24]$. Subsequently, its down-regulation has been confirmed in glioma and renal cell carcinoma tissues and cell lines where CASC2 exerts its tumor suppressive role through down-regulation of miR-21 $[25,26]$. In lung cancer, its down-regulation was significantly correlated with advanced tumor, node and metastasis (TNM) stage and tumor size indicating its role as an independent predictor for overall survival (OS) of these patients [27]. Furthermore, lower expression of this IncRNA in CRC patients was associated with advanced TNM stage. In vitro studies have shown that it functions as a competing endogenous RNA (ceRNA) for miR-18 leading to up-re- gulation of expression of PIAS3 and STAT3 downstream genes and subsequent suppression of CRC cell proliferation [28]. More recently, its aberrant expression has been demonstrated in hepatocellular carcinoma (HCC) and gastric cancer where it has been shown to exert its role via inhibition of MAPK pathway [29,30]. In CASC2 overexpressed CRC cells, phosphorylation of ERK and JNK was decreased showing the role of CASC2 in inhibition of the MAPK pathway [29].

\section{Colon cancer-associated \\ transcript-1 (CCAT1)}

The expression levels of CCAT1 increase in a variety of tumors including medulloblastoma. Its silencing has remarkably suppressed cell proliferation, induced cell cycle arrest in medulloblastoma cells and decreased phosphorylated levels of MAPK, ERK and MEK. So the oncogenic roles of CCAT1 in medulloblastoma is possibly exerted via regulating the MAPK pathway [31].

\section{Colorectal neoplasia differentially expressed (CRNDE)}

The elevated expression of this IncRNA has been detected in colorectal adenomas and cancers compared with normal colon epithelia [32]. In addition, high plasma levels of a certain splice variant of CRNDE is a putative plasma biomarker for CRC with a sensitivity of $87 \%$ and specificity of $93 \%$ [32]. Upregulation of this IncRNA has been demonstrated in lymphocytic leukemias as well as various solid tumors [33]. Notably, in addition to anti-apoptotic effects, CRNDE has a role in enhancement of proliferation, migration and invasion of glioma stem cells [34]. Its over-expression has been associated with poor patients' outcome in ovarian cancer [35] and CRC patients [36]. More recently, over-expression of this IncRNA has been demonstrated in a large cohort of CRC patients with remarkable associations between its high expression and advanced cancer stages as well as poor prognosis [37]. Notably, the mRNA expression profile of CRNDE-knocked out CRC cells shows its regulatory function on the Ras and MAPK pathways.
In addition, many of CRNDE-induced Ras/MAPK signaling genes participate in CRC development [37].

\section{Cytoskeleton regulator RNA (CYTOR)} This intergenic IncRNA has a crucial role in cell proliferation, cell migration, and cytoskeletal organization. Its expression has been increased in all subtypes of breast cancer as well as a variety of other malignancies including thyroid, stomach, lung, renal, and liver cancers. Using an innovative method based on the recognition of correlations between the expression of IncRNA and proteincoding genes which participate in certain functions, CYTOR has been shown to be associated with the epidermal growth factor receptor (EGFR), mammalian target of rapamycin (mTOR), and MAPK pathways [38].

Insulin-like growth factor 2 antisense 1 (Igf2as)

The expression of this IncRNA has been increased in HCC cells and tissues. Its silencing inhibited cell proliferation and migration and induced apoptosis through inactivation of ERK/MAPK signaling pathway [39].

\section{LincRNA regulator of reprogramming (linc-RoR)}

This IncRNA was initially recognized to alter reprogramming of induced pluripotent stem cells [40]. Subsequently, it has been demonstrated to act as a miRNA sponge which changes the expression of the principal transcription factors in human embryonic stem cells [41]. Besides, it both inhibits p53 translation [42] and enhances c-Myc expression through interaction with heterogeneous nuclear ribonucleoprotein I (hnRNP I) [43]. While in triple negative breast cancer, linc-RoR increases cell invasion via miR-145/ARF6 pathway [44], in estrogen receptor positive breast tumors it activates MAPK/ERK pathway through diminishing the stability of dual specificity phosphatase 7 (DUSP7) which down-regulates ERK [45].

\section{LncRNA-AWPPH}

This IncRNA has been firstly identified as an over-expressed IncRNA in HCC 
whose expression was correlated with invasion, advanced TNM stage as well as poor recurrence-free and OS. In vitro studies have shown its interaction with Y-Box Binding Protein 1 (YBX1) which leads to up-regulation of SNAIL1 and PIK3CA expressions and activation of the $\mathrm{PI3K} / \mathrm{AKT}$ pathway [46].

\section{Lnc00462717}

In glioma tissues, its low expression was associated with the malignant status. In vitro studies have shown its suppressive effect on glioma cell proliferation, survival and migration, which is possibly due to its negative effect on MDM2 expression. In addition, it has a regulatory role on MAPK pathway through decreasing the phosphorylation of p38, ERK1/2, and JNK [47].

\section{LncRNA-low expression in tumor (LET)}

It is a tumor suppressor IncRNA, which is down-regulated in a variety of malignancies including nasopharyngeal carcinoma (NPC). In vitro studies have demonstrated its role in regulation of cell proliferation, adhesion and invasion of NPC through modulation of MAPK/ERK pathway genes. p-ERK1/2 and p-MEK were considerably down-regulated in LET over-expressed cells with no change in total-ERK1/2 and total-MEK levels. So $L E T$ inhibits the cell growth and invasion of NPC cells via suppression of ERK signaling pathway [48].

\section{Metastasis-associated lung adenocarcinoma transcript 1 (MALAT1)}

This IncRNA has been known as an oncogene associated with metastasis potential of several cancers. MALAT1 enhances cancer cell migration and the EMT by modulation of the expression of several genes [49]. MALAT1 silencing in gall bladder cancer (GBC) cell lines has led to suppression of the proliferation and metastasis of these cell in addition to down-regulation of the expression of phosphorylated MEK1/2, ERK 1/2, MAPK, and JNK $1 / 2 / 3$ leading to inhibition of MAPK pathway [50]. Moreover, knockout of MALAT1 in lung cancer cells has resulted in down-regulation of numerous metastasis related genes including Glypican 6 (GPC6) and C-X-C motif chemokine 5 (CXCL5) [51] both of which participate in regulation of MAPK pathway [52,53]. Notably, MALAT1 has been one of the most considerably up-regulated IncRNAs during neuroblastoma-derived Neuro-2a (N2a) cell differentiation whose silencing has impaired neurite outgrowth and induced cell death possibly via inactivation of MAPK signaling pathway as well as aberrant activation of Peroxisome proliferator-activated receptor (PPAR) and P53 signaling pathway [54].

\section{Metastatic renal cell carcinoma-} -associated transcript 1 (MRCCAT1) This IncRNA is over-expressed in metastatic clear cell renal cell carcinoma (ccRCC) tissues. Its expression is associated with the metastatic phenotype of these cells as well as patients' outcome. MRCCAT1 inhibits Natriuretic Peptide Receptor 3 (NPR3) transcription by recruiting polycomb repressive complex 2 (PRC2) to NPR3 promoter leading to activation of p38-MAPK signaling pathway. Forced over-expression of this IncRNA has resulted in elevation of phosphorylated p38 levels while the phosphorylation levels of ERK and JNK have not been altered [55].

\section{Maternally expressed gene 3 (MEG3)} This imprinted gene is expressed in a variety of normal tissues [56]. On the other hand, its expression has been decreased or lost in several tumors including glioma [57], meningiomas [58], hepatoma [59], gastric cancer [60] and breast cancer [61]. Its tumor suppressive effects have been demonstrated by several in vitro studies $[57,60]$. In breast cancer cells, it has a fundamental role in regulation of cell proliferation and invasion as well as expression of angiogenesis-related factors which is at least partially exerted through AKT signaling pathway [61].

\section{Melanoma highly expressed noncoding RNA (MHENCR)}

Its expression has been increased in melanoma tissues and metastatic melanoma in association with poor survival of melanoma patients. Its silencing has resulted in inhibition of cells proliferation and migration as well as enhancement of cell cycle arrest and apoptosis. It acts as a ceRNA for miR-425 and miR-489 leading to over-expression of their target genes IGF1 and SPIN1 and subsequent activation of PI3K-Akt pathway [62]. Considering the role of miR-489 in regulation of MAPK signaling [63], MHENCR might be involved in regulation of this pathway as well.

\section{PTEN pseudogene-1 (PTENP1)}

Its over-expression in MCF7 breast cancer cells has resulted in inhibition of cell proliferation and migration as well as down-regulation of cyclin A2, CDK2, p-AKT, p-p44/42 MAPK and p-p38 MAPK, so this IncRNA can impede the proliferation and migration of breast cancer cells through modulation of AKT and MAPK signaling pathways [64].

\section{RMEL3 (ENSG00000250961)}

Elevated expression of RMEL3 in melanoma is significantly linked with the existence of BRAF ${ }^{\mathrm{V} 600 \mathrm{E}}$ mutation. Its knock-down has considerably decreased colony formation in melanoma cell lines that harbor this mutation. Its expression levels have been correlated with the expression of several MAPK and PI3K pathways genes. Besides, its silencing has diminished expression of PAKT and BRAF in addition to several activators or effectors of MAPK and PI3K pathways such as FGF2, FGF3, DUSP6, ITGB3 and GNG2. Consequently, both in silico analysis and experimental data confirmed its role in MAPK and PI3K signaling [65].

\section{Taurine-upregulated gene 1 (TUG1)} This IncRNA has a role in regulation of gene expression through engagement of PRC2. Its down-regulation has been demonstrated in a variety of cancers including non-small cell lung carcinoma (NSCLC) tissues in which its downexpression has been associated with higher TNM stage and tumor size, as well as poor patients' outcome. It has been shown to be a direct transcriptional target of p53 whose silencing leads to enhancement of cell proliferation and 
up-regulation of homeobox B7 (HOXB7) expression. As the levels of $p$-ERK, $p$-AKT and $p-G S K 3 b$ were increased following TUG1 silencing, it has been hypothesized that TUG1 contributes in AKT/MAPK pathway through modulation of HOXB7 expression [66].

\section{Urothelial carcinoma associated 1 (UCA1)}

This IncRNA has an oncogenic role in human bladder cancer pathogenesis. Its silencing has resulted in downregulation of $\mathrm{p} 300$ (encoded by EP300) and its coactivator CAMP response element-binding protein (CREB). In addition, UCA1 modulates AKT activity and cell cycle progression through CREB [67]. CREB is also been phosphorylated through activation of MAPK-interacting kinase (MNK) in MAPK cascade [68].

\section{Up-regulated in hepatocellular carcinoma (URHC)}

Up-regulation of this IncRNA in HCC cell lines has been demonstrated through using IncRNA microarray. In addition, its over-expression in HCC tissues has been correlated with poor OS. In vitro studies have shown its role in modulation of cell proliferation and apoptosis through down-regulation of leucine zipper containing kinase AZK (ZAK). ERK, JNK and p38 kinase phosphorylation has been altered in URHC knocked-down cells, which implies that the role of $U R H C$ in modulation of cell growth and apoptosis might be exerted through inactivation of the MAPK signaling pathway. Consequently, URHC regulates cell proliferation and apoptosis via ERK/MAPK inhibition by targeting ZAK [69].

\section{Discussion}

Recent studies have demonstrated that IncRNA signature can be used as biomarker and target of novel treatment strategies in cancer patients $[70,71]$. LncRNAs participate in principal cancer-related processes, such as cell proliferation, cell migration, and EMT through the modulation of important signaling pathways including mTOR and MAPK pathways [38]. A comprehensive genome-wide transcriptional in- vestigation of IncRNA signature in breast cancer samples has led to identification of IncRNA specific profile in breast cancer subtypes. Of note, among the nine IncRNAs that constitute the luminal $B$ signature, one chief IncRNA category was linked to the MAPK pathway [38]. Considering the prominent role of MAPK pathway in the pathogenesis of melanoma and existence of MAPK targeting therapeutic modalities in melanoma [72], expression analysis of MAPK-related IncRNAs in this kind of cancer is of special significance.

LncRNAs regulatory roles in fundamental cellular pathways are exerted through modulation of gene expression at the transcriptional or posttranscriptional level. Some of their functions have been elaborated, while others need to be clarified. For instance, the regulatory role of CRNDE in regulation of MAPK pathway in CRC [37] and in the maintenance of glioma stem cells [34] have been demonstrated. Considering the role of MAPK in glioma stem cells [73], future studies are needed to elucidate the functional link between the MAPK pathway, CRNDE and stem cell maintenance in glioma. Besides, consistent with the existence of a complex interaction network between IncRNAs, miRNAs and protein coding genes especially in the context of cancer, CASC2 has been shown to exert its tumor suppressive role via modulation of both miRNAs and protein coding genes including those located in MAPK pathway $[25,26,29]$. Additionally, as revealed by independent studies, a certain IncRNA might regulate expression of different pathways in distinct types of cancers. For instance, while MALAT1 activates MAPK pathway in GBC [50], it induces the phosphoinositide 3-kinase (PI3K/Akt) pathway in osteosarcoma cells without any significant alteration in MAPK pathway in these cells [74].

Notably, IncRNA-AWPPH and UCA 1 possibly participate in cross-talk between MAPK and PI3K/Akt pathways through regulation of certain shared proteins between these pathways. Previous reports have demonstrated that these two signaling pathways interact with each other at multiple levels. However, as revealed by both in silico and experimental studies, such interactions are context-dependent [75] which is in line with the proposed backgroundreliant role of IncRNAs in regulation of these pathways.

Considering the advent of pathwaybased therapeutic modalities for cancer especially in the context of precision medicine [76], expression analysis of IncRNAs that modulate certain cancer related pathways is of clinical importance. Future studies are needed to elaborate function of IncRNAs in these pathways in each cancer type.

\section{References}

1. Schaeffer HJ, Weber MJ. Mitogen-activated protein kinases: Specific messages from ubiquitous messengers. Mol Cell Biol 1999: 19(4): 2435-2444.

2. Sebolt-Leopold JS, Herrera R. Targeting the mitogenactivated protein kinase cascade to treat cancer. Nat Rev Cancer 2004; 4(12): 937-947. doi: 10.1038/nrc1503.

3. Li R, Zhang $L$, Jia $L$ et al. Long non-coding RNA BANCR promotes proliferation in malignant melanoma by regulating MAPK pathway activation. Plos One 2014; 9(6): e100893. doi: 10.1371/journal.pone.0100893.

4. Soudyab M, Iranpour M, Ghafouri-Fard S. The role of long non-coding RNAs in breast cancer. Arch Iran Med 2016; 19(7): 508-517. doi: 0161907/AIM.0011.

5. Iranpour M, Soudyab M, Geranpayeh L et al. Expression analysis of four long noncoding RNAs in breast cancer. Tumour Biol 2016; 37(3): 2933-2940. doi: 10.1007/s13277015-4135-2.

6. Nikpayam E, Tasharrofi B, Sarrafzadeh S et al. The role of long non-coding RNAs in ovarian cancer. Iran Biomed J 2017; 21(1): 3-15. doi: 10.6091/.21.1.24.

7. Dianatpour A, Ghafouri-Fard S. Long non coding RNA expression intersecting cancer and spermatogenesis: A systematic review. Asian Pac J Cancer Prev 2017; 18(10): 2601-2610. doi: 10.22034/APJCP.2017.18.10. 2601.

8. Dianatpour A, Ghafouri-Fard S. The role of long non coding RNAs in the repair of dna double strand breaks. Int J Mol Cell Med 2017; 6(1): 1-12.

9. Melissari MT, Grote P. Roles for long non-coding RNAs in physiology and disease. Pflugers Archiv 2016; 468(6): 945-958. doi: 10.1007/s00424-016-1804-y.

10. Sarrafzadeh S, Geranpayeh L, Ghafouri-Fard S. Expression analysis of long non-coding PCAT-1 in breast cancer. Int J Hematol Oncol Stem Cell Res 2017; 11(3): 185-191. 11. Nikpayam E, Soudyab M, Tasharrofi B et al. Expression analysis of long non-coding ATB and its putative target in breast cancer. Breast Dis 2017; 37(1): 11-20. doi: 10.3233/BD-160264.

12. Khorshidi HR, Taheri M, Noroozi R et al. ANRIL genetic variants in iranian breast cancer patients. Cell J 2017; 19 (Suppl 1): 72-78. doi: 10.22074/cellj.2017.4496.

13. Taheri M, Pouresmaeili F, Omrani MD et al. Association of ANRIL gene polymorphisms with prostate cancer and benign prostatic hyperplasia in an Iranian population. Biomark Med 2017; 11(5): 413-422. doi: 10.2217/bmm2016-0378.

14. Taheri M, Habibi M, Noroozi R et al. HOTAIR genetic variants are associated with prostate cancer and benign prostate hyperplasia in an Iranian population. Gene 2017; 613: 20-24. doi: 10.1016/j.gene.2017.02.031. 
15. Khorshidi HR, Taheri M, Noroozi R et al. Investigation of the association of HOTAIR single nucleotide polymorphisms and risk of breast cancer in an iranian population. Int J Cancer Manag 2017; 10(5): e7498. doi: 10.5812/ijcm.7498

16. Sarrafzadeh S, Geranpayeh L, Tasharrofi B et al. Expression study and clinical correlations of MYC and CCAT2 in breast cancer patients. Iran Biomed J 2017:21(5):303-311. 17. Tasharrofi B, Soudyab M, Nikpayam E et al. Comparative expression analysis of hypoxia-inducible factor-alpha and its natural occurring antisense in breast cancer tissues and adjacent noncancerous tissues. Cell Biochem Funct 2016; 34(8): 572-578. doi: 10.1002/cbf.3230.

18. Xu XC, Wan XF, Zhang ZR. Long non-coding RNA ANRIL promotes tumorigenesis in glioma via MAPK signaling pathways. Int J Clin Exp Patho 2016; 9(10): 10803-10809.

19. Gooding AJ, Zhang B, Jahanbani FK et al. The IncRNA BORG drives breast cancer metastasis and disease recurrence. Sci Rep 2017; 7: 12698. doi: 10.1038/s41598-01712716-6.

20. Wang DN, Wang DB, Wang $N$ et al. Long non-coding RNA BANCR promotes endometrial cancer cell proliferation and invasion by regulating MMP2 and MMP1 via ERK/MAPK signaling pathway. Cell Physiol Biochem 2016; 40(3-4): 644-656. doi: 10.1159/000452577.

21. Quo QH, Zhao Y, Chen JJ et al. BRAF-activated long non-coding RNA contributes to colorectal cancer migration by inducing epithelial-mesenchymal transition. Oncol Lett 2014; 8(2): 869-875. doi: 10.3892/ol.2014.2154. 22. Jiang WJ, Zhang DD, Xu BN et al. Long non-coding RNA BANCR promotes proliferation and migration of lung carcinoma via MAPK pathways. Biomed Pharmacother 2015; 69: 90-95. doi: 10.1016/j.biopha.2014.11.027.

23. Baldinu P, Cossu A, Manca A et al. Identification of a novel candidate gene, CASC2, in a region of common allelic loss at chromosome 10q26 in human endometrial cancer. Hum Mutat 2004; 23(4): 318-326. doi: 10.1002/humu.20015

24. Baldinu P, Cossu A, Manca A et al. CASC2a gene is down-regulated in endometrial cancer. Anticancer Res 2007; 27(1A): 235-243.

25. Wang P, Liu YH, Yao YL et al. Long non-coding RNA CASC2 suppresses malignancy in human gliomas by miR-21. Cell Signal 2015; 27(2): 275-282. doi: 10.1016/j. cellsig.2014.11.011

26. Cao Y, Xu R, Xu X et al. Downregulation of IncRNA CASC2 by microRNA-21 increases the proliferation and migration of renal cell carcinoma cells. Mol Med Rep 2016; 14(1): 1019-1025. doi: 10.3892/mmr.2016.5337. 27. He X, Liu Z, Su J et al. Low expression of long noncoding RNA CASC2 indicates a poor prognosis and regulates cell proliferation in non-small cell lung cancer. Tumour Biol 2016; 37(7): 9503-9510. doi: 10.1007/s13277-0164787-6.

28. Huang G, Wu X, Li S et al. The long noncoding RNA CASC2 functions as a competing endogenous RNA by sponging miR-18a in colorectal cancer. Sci Rep 2016 20; 6: 26524. doi: 10.1038/srep26524.

29. Gan $Y$, Han N, He X et al. Long non-coding RNA CASC2 regulates cell biological behaviour through the MAPK signalling pathway in hepatocellular carcinoma. Tumor Biol 2017; 39(6): 1010428317706229 . doi: 10.1177/1010428317706229.

30. Li P, Xue WJ, Feng $Y$ et al. Long non-coding RNA CASC2 suppresses the proliferation of gastric cancer cells by regulating the MAPK signaling pathway. Am J Transl Res 2016; 8(8): 3522-3529.

31. Gao R, Zhang R, Zhang $C$ et al. Long noncoding RNA CCAT1 promotes cell proliferation and metastasis in human medulloblastoma via MAPK pathway. Tumori 2017: 0. doi: 10.5301/tj.5000662.

32. Graham LD, Pedersen SK, Brown GS et al. Colorectal neoplasia differentially expressed (CRNDE), a novel gene with elevated expression in colorectal adenomas and adenocarcinomas. Genes Cancer 2011; 2(8): 829-840. doi: 10.1177/1947601911431081.

33. Ellis BC, Molloy PL, Graham LD. CRNDE: a long non-coding RNA involved in cancer, neurobiology, and development. Front Genet 2012; 3: 270. do: 10.3389/fgene.2012.00270.

34. Zheng J, Li X, Wang P et al. CRNDE affects the malignant biological characteristics of human glioma stem cells by negatively regulating miR-186. Oncotarget 2015; 6(28): 25339-25355. doi: 10.18632/oncotarget.4509. 35. Szafron LM, Balcerak A, Grzybowska EA et al. The putative oncogene, CRNDE, is a negative prognostic fac tor in ovarian cancer patients. Oncotarget 2015; 6(41): 43897-43910. doi: 10.18632/oncotarget.6016.

36. Liu T, Zhang X, Yang Y et al. Increased expression of the long noncoding RNA CRNDE-h indicates a poor prognosis in colorectal cancer, and is positively correlated with IRX5 mRNA expression. Onco Targets Ther 2016; 9 ; 1437-1448. doi: 10.2147/OTT.S98268.

37. Jiang $\mathrm{H}$, Wang $Y$, Ai $\mathrm{M}$ et al. Long noncoding RNA CRNDE stabilized by hnRNPUL2 accelerates cell proliferation and migration in colorectal carcinoma via activating Ras/MAPK signaling pathways. Cell Death Dis 2017; 8(6): e2862. doi: 10.1038/cddis.2017.258

38. Van Grembergen O, Bizet M, de Bony EJ et al. Portraying breast cancers with long noncoding RNAs. Sci Adv 2016; 2(9): e 1600220. doi: 10.1126/sciadv.1600220.

39. Bao H, Guo CG, Qiu PC et al. Long non-coding RNA Igf2as controls hepatocellular carcinoma progression through the ERK/MAPK signaling pathway. Onco Lett 2017; 14(3): 2831-2837. doi: 10.3892/ol.2017. 6492

40. Loewer S, Cabili MN, Guttman M et al. Large intergenic non-coding RNA-RoR modulates reprogramming of human induced pluripotent stem cells. Nat Genet 2010 42(12): 1113-1117. doi: 10.1038/ng.710.

41. Wang $Y, X u Z$, Jiang J et al. Endogenous miRNA sponge lincRNA-RoR regulates Oct4, Nanog, and Sox2 in human embryonic stem cell self-renewal. Dev Cell 2013; 25(1): 69-80. doi: 10.1016/j.devcel.2013.03.002.

42. Zhang A, Zhou N, Huang J et al. The human long non-coding RNA-RoR is a p53 repressor in response to DNA damage. Cell Res 2013; 23(3): 340-350. do: 10.1038/cr.2012.164.

43. Huang J, Zhang A, Ho TT et al. Linc-RoR promotes c-Myc expression through hnRNP I and AUF1. Nucleic Acids Re 2016; 44(7): 3059-3069. doi: 10.1093/nar/gkv1353.

44. Eades $G$, Wolfson B, Zhang $Y$ et al. LincRNA-RoR and miR-145 regulate invasion in triple-negative breast cance via targeting ARF6. Mol Cancer Res 2015; 13(2): 330-338. doi: 10.1158/1541-7786.MCR-14-0251.

45. Peng WX, Huang JG, Yang L et al. Linc-RoR promotes MAPK/ERK signaling and confers estrogen-independent growth of breast cancer. Mol Cancer 2017; 16(1): 161. doi 10.1186/s12943-017-0727-3.

46. Zhao XD, Liu YB, Yu S. Long noncoding RNA AWPPH promotes hepatocellular carcinoma progression through YBX1 and serves as a prognostic biomarker. Biochim Biophys Acta 2017; 1863(7): 1805-1816. doi: 10.1016/ bbadis.2017.04.014

47. Wang $A Q$, Meng MZ, Zhao XH et al. Long non-cod ing RNA ENST00462717 suppresses the proliferation, survival, and migration by inhibiting MDM2/MAPK pathway in glioma. Biochem Biophys Res Commun 2017: 485(2): 513-521. doi: 10.1016/j.bbrc.2017.02.015.

48. Chen L, Sun L, Dong L et al. The role of long noncod ing RNA-LET in cell proliferation and invasion of nasopharyngeal carcinoma and its mechanism. Onco Targets The 2017; 10: 2769-2778. doi: 10.2147/OTT.S126907.

49. Ying L, Chen Q, Wang Y et al. Upregulated MALATcontributes to bladder cancer cell migration by inducing epithelial-to-mesenchymal transition. Mol Biosyst 2012; 8(9): 2289-2294. doi: 10.1039/c2mb25070e.
50. Wu XS, Wang XA, Wu WG et al. MALAT1 promotes the proliferation and metastasis of gallbladder cancer cells by activating the ERK/MAPK pathway. Cancer Biol Ther 2014; 15(6): 806-814. doi: 10.4161/cbt.28584

51. Gutschner $T$, Hämmerle $M$, Eißmann $M$ et al. The noncoding RNA MALAT1 is a critical regulator of the metastasis phenotype of lung cancer cells. Cancer Res 2013: 73(3): 1180-1189. doi: 10.1158/0008-5472.CAN-122850.

52. Yiu GK, Kaunisto A, Chin YR et al. NFAT promotes carcinoma invasive migration through glypican-6. Biochemical J 2011; 440(1): 157-166. doi: 10.1042/BJ20110 530

53. Merabova N, Kaminski R, Krynska B et al. JCV agnoprotein-induced reduction in CXCL5/LIX secretion by oligodendrocytes is associated with activation of apoptotic signaling in neurons. J Cell Physiol 2012; 227(8): 3119-3127. doi: 10.1002/jcp.23065.

54. Chen L, Feng PM, Zhu X et al. Long non-coding RNA Malat1 promotes neurite outgrowth through activation of ERK/MAPK signalling pathway in N2a cells. J Cell Mol Med 2016; 20(11): 2102-2110. doi: 10.1111/jcmm 12904. 55. Li JK, Chen C, Liu JY et al. Long noncoding RNA MRCCAT1 promotes metastasis of clear cell renal cell carcinoma via inhibiting NPR3 and activating p38MAPK signaling. Mol Cancer 2017; 16(1): 111. doi: 10.1186/s12943-017-0681-0.

56. Zhang X, Zhou YL, Mehta KR et al. A pituitary-derived MEG3 isoform functions as a growth suppressor in tumor cells. J Clin Endocrinol Metab 2003; 88(11): 5119-5126. doi: 10.1210/jc.2003-030222.

57. Wang PJ, Ren ZQ Sun PY. Overexpression of the long non-coding RNA MEG3 impairs in vitro glioma cell proliferation. J Cell Biochem 2012; 113(6): 1868-1874. doi: 10.1002/jcb.24055

58. Zhang X, Gejman R, Mahta A et al. Maternally expressed gene 3 , an imprinted noncoding RNA gene, is associated with meningioma pathogenesis and progression. Cancer Res 2010; 70(6): 2350-2358. doi: 10.1158/0008-5472.CAN-09-3885.

59. Zhu J, Liu S, Ye F et al. Long Noncoding RNA MEG3 Interacts with p53 protein and regulates partial p53 target genes in hepatoma cells. Plos One 2015; 10(10): e0139790. doi: 10.1371/journal.pone.0139790.

60. Sun M, Xia R, Jin F et al. Downregulated long noncoding RNA MEG3 is associated with poor prognosis and promotes cell proliferation in gastric cancer. Tumour biology 2014: 35(2): 1065-1073. doi: 10.1007/s13277-013-1142-z. 61. Zhang CY, Yu MS, Li X et al. Overexpression of long non-coding RNA MEG3 suppresses breast cancer cell proliferation, invasion, and angiogenesis through AKT pathway. Tumour Biol 2017; 39(6): 1010428317701311. doi: 10.1177/1010428317701311.

62. Chen XJ, Dong H, Liu S et al. Long noncoding RNA MHENCR promotes melanoma progression via regulating miR-425/489-mediated PI3K-Akt pathway. Am J Transl Res 2017: 9(1): 90-102

63. Patel Y, Shah N, Lee JS et al. A novel double-negative feedback loop between miR-489 and the HER2SHP2-MAPK signaling axis regulates breast cancer cell proliferation and tumor growth. Oncotarget 2016; 7(14): 18295-18308. doi: 10.18632/oncotarget.7577. 64. Chen S, Wang Y, Zhang JH et al. Long non-coding RNA PTENP1 inhibits proliferation and migration of breast cancer cells via AKT and MAPK signaling pathways. Oncol Lett 2017; 14(4): 4659-4662. doi: 10.3892/ol.2017.6823. 65. Goedert L, Pereira CG, Roszik J et al. RMEL3, a novel BRAFV600E-associated long noncoding RNA, is required for MAPK and PI3K signaling in melanoma. Oncotarget 2016; 7(24): 36711-36718. doi: 10.18632/oncotarget. 9164

66. Zhang EB, Yin DD, Sun M et al. P53-regulated long non-coding RNA TUG1 affects cell proliferation in human non-small cell lung cancer, partly through epigenetica- 
Ily regulating HOXB7 expression. Cell Death Dis 2014; 5: e1243. doi: 10.1038/cddis.2014.201.

67. Yang $C$, Li X, Wang Y et al. Long non-coding RNA UCA1 regulated cell cycle distribution via CREB through PI3-K dependent pathway in bladder carcinoma cells. Gene 2012; 496(1): 8-16. doi: 10.1016/j.gene.2012.01.012. 68. Cargnello M, Roux PP. Activation and function of the MAPKs and their substrates, the MAPK-activated protein kinases (vol 75, pg 50, 2011). Microbiol Mol Biol Rev 2012; 76(2): 496. doi: 10.1128/MMBR.00013-12

69. Xu WH, Zhang JB, Dang Z et al. Long Non-coding RNA URHC regulates cell proliferation and apoptosis via ZAK through the ERK/MAPK signaling pathway in hepatocelIular carcinoma. Int J Biol Sci 2014; 10(7): 664-676. doi: $10.7150 /$ ijbs.8232.
70. Taheri M, Omrani MD, Ghafouri-Fard S. Long non-coding RNAs expression in renal cell carcinoma. Journal of Biology and Today's World 2017; 6(12): 240-247.

71. Faramarzi S, Dianatpour A, Ghafouri-Fard S. Discover ing the role of long non-coding RNAs in regulation of steroid receptors signaling in cancer. Journal of Biology and Today's World 2017; 6(12): 248-258.

72. Inamdar GS, Madhunapantula SV, Robertson GP. Targeting the MAPK pathway in melanoma: Why some approaches succeed and other fail. Biochem Pharmacol 2010; 80(5): 624-637. doi: 10.1016/j.bcp.2010.04 029 .

73. Riddick G, Kotliarova S, Rodriguez $\vee$ et al. A core regulatory circuit in glioblastoma stem cells links MAPK activation to a transcriptional program of neural stem cell identity. Sci Rep 2017; 7: 43605. doi: 10.1038/srep43 605.

74. Dong YQ, Liang GJ, Yuan B et al. MALAT1 promotes the proliferation and metastasis of osteosarcoma cells by activating the PI3K/Akt pathway. Tumour Biol 2015; 36(3): 1477-1486. doi: 10.1007/s13277-014-2631-4.

75. Aksamitiene E, Kiyatkin A, Kholodenko BN. Crosstalk between mitogenic Ras/MAPK and survival PI3K/Akt pathways: a fine balance. Biochemical Soc Trans 2012; 40(1): 139-146. doi: 10.1042/BST20110609.

76. Taylor AD, Micheel CM, Anderson IA et al. The path (way) less traveled: a pathway-oriented approach to providing information about precision cancer medicine on my cancer genome. Transl Oncol 2016; 9(2): 163-165. doi: 10.1016/j.tranon.2016.03.001. 